2017-12

\title{
Algal polysaccharide utilisation by saprotrophic planktonic marine fungi
}

Cunliffe, Michael

http://hdl.handle.net/10026.1/10392

10.1016/j.funeco.2017.08.009

Fungal Ecology

Elsevier

All content in PEARL is protected by copyright law. Author manuscripts are made available in accordance with publisher policies. Please cite only the published version using the details provided on the item record or document. In the absence of an open licence (e.g. Creative Commons), permissions for further reuse of content should be sought from the publisher or author. 
Short Communication

\title{
Algal polysaccharide utilisation by saprotrophic planktonic marine fungi
}

\author{
Michael Cunliffe a, b, *, Anita Hollingsworth a , Cal Bain ${ }^{\text {a }}$, Vikram Sharma ${ }^{\text {c }}$, Joe D. Taylor a, 1 \\ ${ }^{a}$ Marine Biological Association of the UK, The Laboratory, Citadel Hill, Plymouth, UK \\ ${ }^{\mathrm{b}}$ Marine Biology and Ecology Research Centre, School of Biological and Marine Sciences, Plymouth University, Drake Circus, Plymouth, UK \\ c School of Biomedical and Healthcare Sciences, Plymouth University, Drake Circus, Plymouth, UK
}

\section{A R T I C L E I N F O}

\section{Article history:}

Received 3 July 2017

Received in revised form

21 August 2017

Accepted 30 August 2017

Available online $\mathrm{xxx}$

Corresponding Editor: Felix Bärlocher.

\section{Keywords:}

Marine fungi

Mycoplankton

Saprotrophy

Algal polysaccharides

\begin{abstract}
A B S T R A C T
The functional roles that marine mycoplankton fulfil are poorly understood, resulting in a lack of knowledge of their ecology. Here we show, using DNA Stable Isotope Probing with ${ }^{13} \mathrm{C}$-labelled diatom polysaccharide microgels, that mycoplankton assimilate algal-derived particulate organic carbon (POC), identifying two genera, Malassezia and Cladosporium, which are active saprotrophs in coastal waters. We subsequently isolated polysaccharide-utilising Cladosporium strains from the same ecosystem and that are well-represented in marine mycoplankton assemblages. At the study site, Cladosporium occurs across multiple years and is associated with diatoms. During growth with the polysaccharide laminarin, Cladosporium spp. secrete the extracellular carbohydrate-active enzyme glucan 1,3 - $\beta$-glucosidase. These results show that some marine mycoplankton have a saprotrophic functional role in processing algal polysaccharides. Mycoplankton may, therefore, be involved in the trophic transfer of phytoplankton produced POC in marine food webs, and because bacterioplankton occupy the same niche, potential interactions maybe taking place that are yet to be characterised.
\end{abstract}

() 2017 Elsevier Ltd and British Mycological Society. All rights reserved.

\section{Introduction}

A base-line understanding of the diversity of marine mycoplankton has been established (Richards et al., 2015; Taylor and Cunliffe, 2016; Tisthammer et al., 2016), however the functional roles that fungi fulfil within marine ecosystems remain largely speculative. Marine mycoplankton could be saprotrophic, decomposing particulate organic carbon (POC) via extracellular enzymes and feeding on dissolved organic carbon (DOC) decomposition products osmotrophically (Richards et al., 2012). In support of this theory, by correlating marine mycoplankton abundance and extracellular enzyme activity, a study off Chile indicated that mycoplankton have roles in processing high-molecular-weight (HMW) algal-derived biopolymers (Gutiérrez et al., 2011).

Polysaccharide microgels, including transparent exopolymer particles (TEP), are principally formed from the abiotic coagulation

\footnotetext{
* Corresponding author. Marine Biological Association of the United Kingdom, The Laboratory, Citadel Hill, Plymouth, PL1 2PB, UK.

E-mail address: micnli@mba.ac.uk (M. Cunliffe).

1 Present address: Department of Biology, University of York, Wentworth Way, York, Y010 5DD.
}

of dissolved biogenic precursor molecules and can constitute up to 40\% of marine POC (Passow, 2002; Engel et al., 2004). Phytoplankton, in particular diatoms, are a major source of microgel precursor molecules, which are excreted during regular metabolic processes (Passow, 2002).

Currently there is a lack of direct evidence of marine mycoplankton saprotrophy, including the identity of taxa involved in processing algal-derived POC and the biological mechanisms used (e.g. enzymes). Such information is needed to establish an understanding of the roles that mycoplankton are fulfilling in the marine carbon cycle (Worden et al., 2015). This study used a combination of culture-independent (DNA-SIP and metabarcoding) and culturedependent (cultivation and proteomics) approaches to identify and characterise marine mycoplankton that actively utilise algalderived polysaccharides.

\section{Materials and methods}

${ }^{12} \mathrm{C}$ and ${ }^{13} \mathrm{C}$-labelled polysaccharide microgels were produced from axenic cultures of the marine diatom Phaeodactylum tricornutum using established methods (Taylor and Cunliffe, 2017) (Supplementary Methods; Supplementary Table 1). Surface 
A.

Dinoflagellata
Protalveolata
Mamiellophyceae
Prymnesiophyceae
Telonemia
Picozoa
Cercozoa
Bolidomonas
Chrysophyceae
Diatomea
Dictyochophyceae
Labyrinthulomycetes
MAST-2
MAST-4
MAST-7
Corallochytrium
Fungi
Annelida
Arthropoda
Brachiopoda
Ctenophora
Mollusca

${ }^{13} \mathrm{C}$ enrichment

$-2-1112334566789$
B.

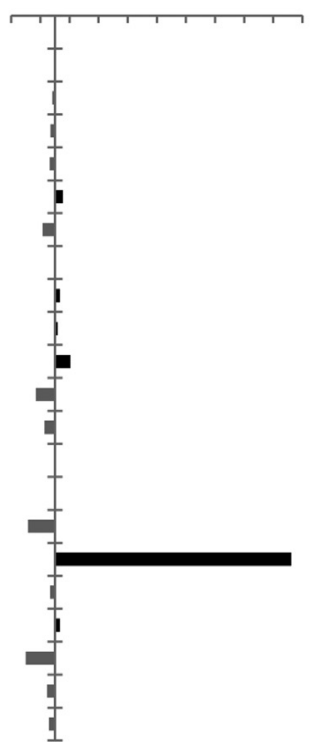

C.

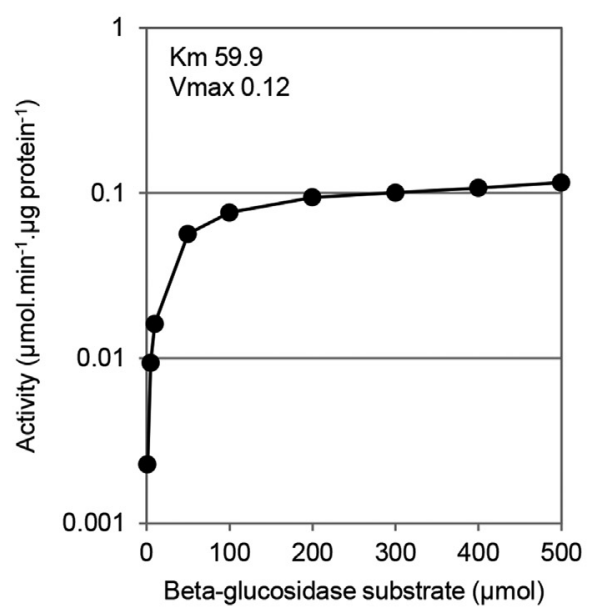

D.

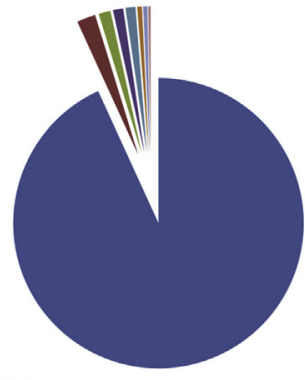

- Glucan 1,3-beta-glucosidase - Uncharacterized protein - Uncharacterized protein - Uncharacterized protein - Phosphoinositide phospholipase - Endosomal peripheral membrane protein - Uncharacterized protein - Methyltransferase TYW3 domain protein

E.

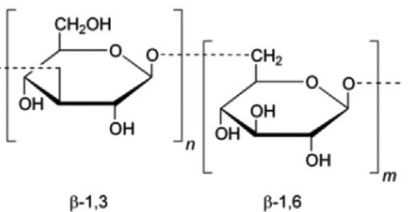

Fig. 1. (A) Comparison of the abundance of $18 \mathrm{~S}$ rRNA gene sequences in libraries created from ${ }^{13} \mathrm{C}$-labelled and ${ }^{12} \mathrm{C}$ control gradient fractions. Taxa $>0$ are those enriched in the ${ }^{13} \mathrm{C}$ libraries relative to the ${ }^{12} \mathrm{C}$ control libraries, indicating that they had assimilated ${ }^{13} \mathrm{C}$-labelled algal polysaccharide. Taxa $<0$ are those not enriched in the ${ }^{13} \mathrm{C}$ libraries, indicating that they had not assimilated the ${ }^{13} \mathrm{C}$-labelled algal polysaccharide. (B) Phylogenetic analysis of the algal polysaccharide-utilising Cladosporium strains FS1 and FS2 isolated from seawater collected from Station L4 and Cladosporium operational taxonomic units (OTUs) in 44 Fungi-specific ITS gene libraries generated by metabarcoding of plankton DNA samples collected between January 2008 and June 2013 from surface waters also at Station L4 (Taylor and Cunliffe, 2016). The tree is based on a maximum likelihood method using a Tamura-Nei model. The numbers on the nodes indicate bootstrap percentages and the scale bar represents sequence divergence. (C) Cladosporium FS2 extracellular $\beta$-glucosidase activity determined by measuring the hydrolysis of 4-methylumbelliferyl $\beta$-D-glucopyranoside (MUFGlc) to the fluorescent 4-methylumbelliferone (MUF) across a range of concentrations in samples loaded in a 96-well plate using a fluorometer (CLARIOstar ${ }^{\circledR}$, BMG Labtech). Maximal velocity (Vmax) and the Michaelis-Menten constant (Km) were calculated via a Lineweaver-Burk plot of the Michaelis-Menten equation: $\mathrm{V}=(\mathrm{Vmax} \times[\mathrm{S}]) /(\mathrm{Km}+[\mathrm{S}])$. (D) Cladosporium FS2 extracellular 'secretome' proteins produced during growth in liquid minimal media with the algal polysaccharide laminarin as a sole carbon and energy source. (E) Chrysolaminarin/laminarin a linear $\beta(1 \rightarrow 3)$ and $\beta(1 \rightarrow 6)$ glucan.

seawater was collected from Station L4 in the Western English Channel (Supplementary Fig. 1; Supplementary Table 2) and used to setup DNA-SIP incubations. After $18 \mathrm{~h}$ incubation, DNA was extracted from filtered seawater samples and DNA-SIP performed using established protocols (Neufeld et al., 2007), with fractions assessed by quantifying buoyant density and DGGE analysis of $18 \mathrm{~S}$ rRNA genes. Specific 'light' and 'heavy' DNA fractions were analysed by sequencing the $\mathrm{V} 9$ region of the $18 \mathrm{~S}$ rRNA gene on an Ion Torrent PGM (Life Technologies) and analysed as previously described (Taylor and Cunliffe, 2014).

P. tricornutum exudates are dominated by chrysolaminarin, a glucan identical to laminarin (Ford and Percival, 1965). We therefore used laminarin to isolate saprotrophic mycoplankton because it is commercially available and chemically defined. Seawater was again collected from Station L4 and plated onto marine minimal agar plates containing laminarin ( $2 \% \mathrm{w} / \mathrm{v}$ ) (Cunliffe, 2016). For assessment of extracellular $\beta$-glucosidase activity and proteomics, after growth in liquid media, biomass was removed by filtration. $\beta$ glucosidase activity was quantified via hydrolysis of 4-methylumbelliferyl $\beta$-D-glucopyranoside (Hoppe, 1983). Extracellular proteins were assessed using LC-MS (Orbitrap, ThermoFisher Scientific), with peptide spectra searched against the Universal Protein 
A.

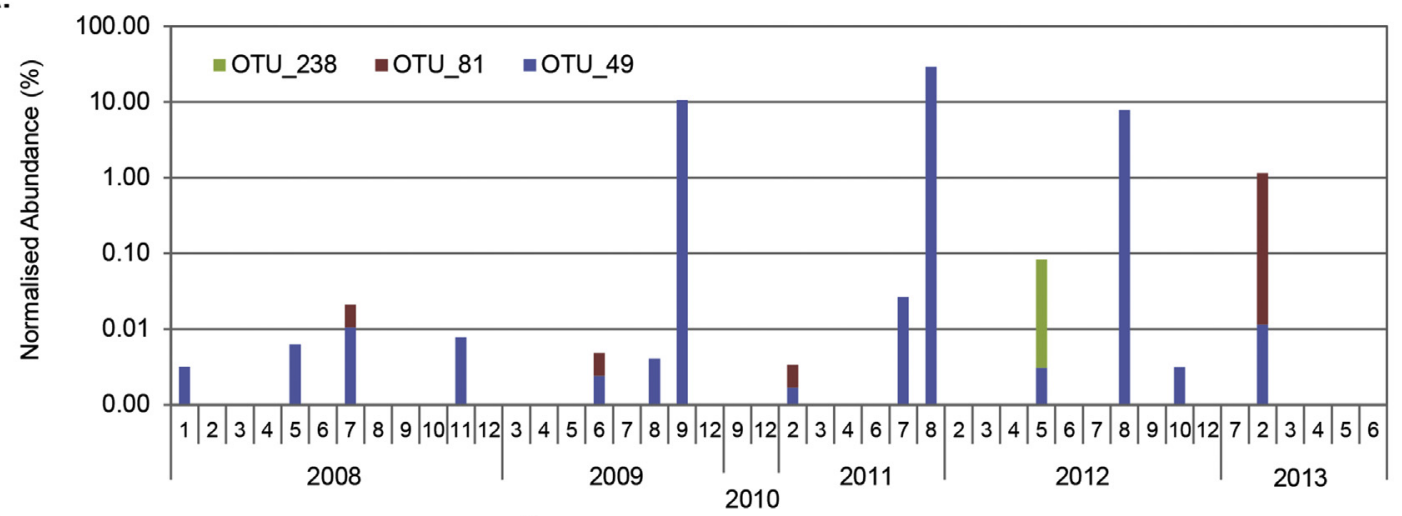

B.

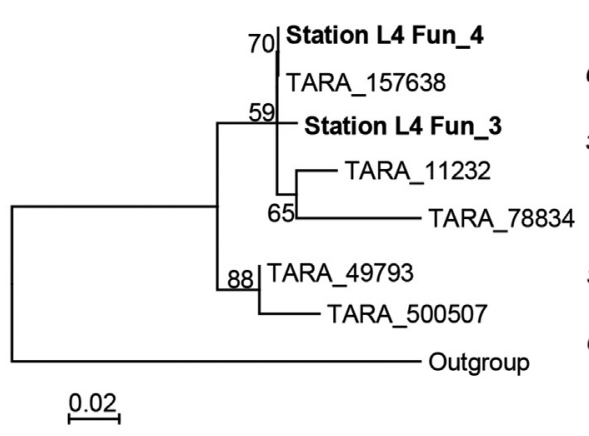

D.

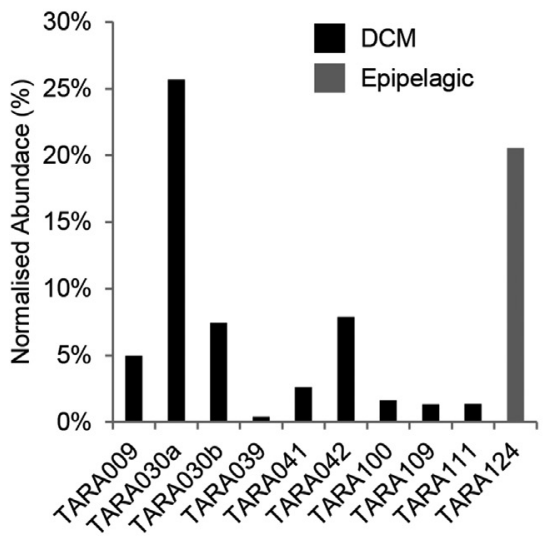

Tara Ocean $18 \mathrm{~S}$ rRNA gene libaries
C.

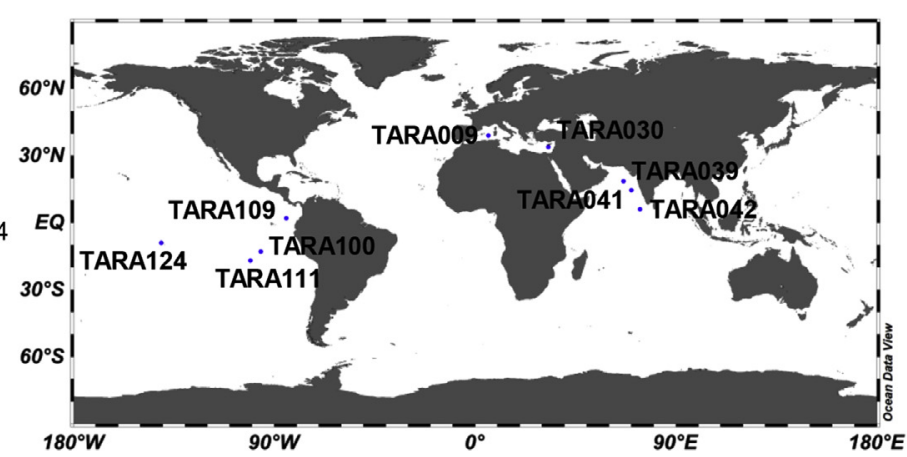

E.

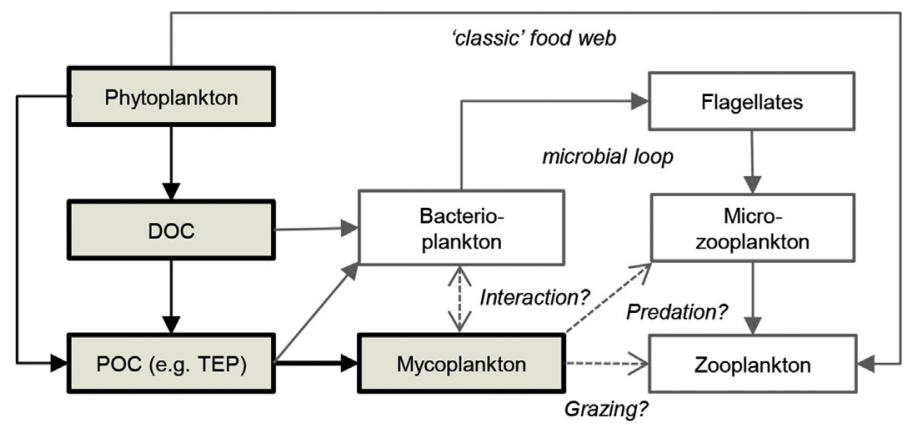

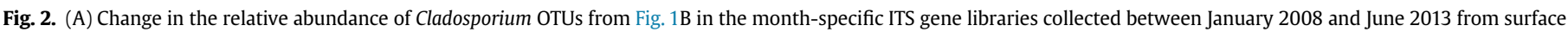

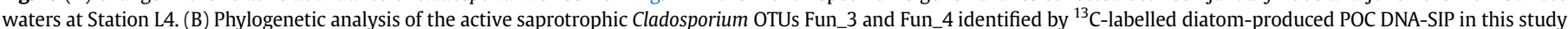

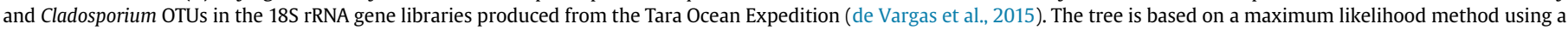

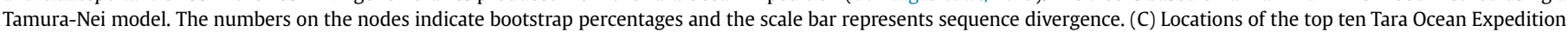

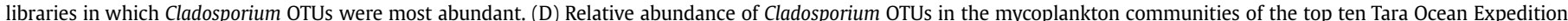

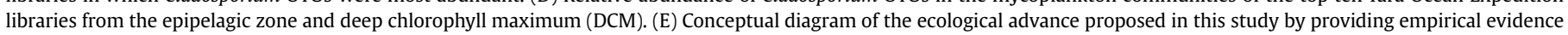
of active marine mycoplankton saprotrophy and identifying specific taxa that utilise algal-derived polysaccharide-based POC with links to phytoplankton.

Resource fungal database.

\section{Results}

Comparison of the 18S rRNA gene libraries generated from the ${ }^{13} \mathrm{C}$-labelled and ${ }^{12} \mathrm{C}$-control fractions showed that fungi were enriched in the ${ }^{13} \mathrm{C}$ incubations relative to other plankton groups (Fig. 1A), showing that mycoplankton had assimilated the polysaccharide containing microgels. Enriched OTUs showed closest matches with the genera Malassezia (Basidiomycota) and
Cladosporium (Ascomycota) (Supplementary Table 3). Two polysaccharide-utilising cultures were subsequently isolated, FS1 and FS2, which were identified by sequencing the PCR amplified ITS region and showing that they both matched the genus Cladosporium (Fig. 1B).

We subsequently focused on Cladosporium FS2 because the strain is related to the most dominant Cladosporium at Station L4 (see below). The FS2 extracellular protein extract showed $\beta$ glucosidase activity (Fig. 1C) and was dominated by the CAZyme glucan 1,3- $\beta$-glucosidase (Fig. 1D, Supplementary Table 4), which 
performs the exohydrolysis of $\beta$-D-glucose units from the nonreducing ends of (1->3)- $\beta$-D-glucans, such as chrysolaminarin (Fig. 1E), and demonstrated that marine Cladosporium have the capacity to decompose diatom polysaccharides.

We examined the distribution of Cladosporium-assigned OTUs in 44 Fungi ITS gene libraries generated from DNA samples collected over 6 yr at Station L4 (Taylor and Cunliffe, 2016). Three OTUs were identified OTU_81,OTU_49 and OTU_238(Fig.1B), with OTU_81 and OTU_49 homologous to the gene sequences amplified from isolates FS1 and FS2 respectively. OTU_49 most frequently occurred at Station L4 and on three occasions was $>1 \%$ of the ITS gene libraries (Fig. 2A). Changes in Cladosporium OTU abundances were compared to fluctuations in co-occurring phytoplankton blooms, including diatoms (Supplementary Fig. 3). Increased OTU_49 abundance was associated with the increased abundance of the diatom genus Leptocylindrus ( $\mathrm{r} 0.909 ; \mathrm{p}<0.01$ ), and the increased abundance OTU_238 associated with the abundance of the diatom genus Chaetoceros ( $\mathrm{r} 0.503 ; \mathrm{p}<0.01$ ). Previous studies have shown that both diatom genera are important TEP producers (Passow, 2002).

To determine the distribution of Cladosporium in the open ocean, the 18S rRNA gene libraries produced from the Tara Ocean Expedition were also examined (de Vargas et al., 2015). Cladosporium OTUs identified in the Station L4 DNA-SIP experiments matched Cladosporium OTUs in the Tara libraries (Fig. 2B). The top ten Tara libraries in which Cladosporium OTUs were most abundant included sites in the Pacific and Indian Oceans (Fig. 2C). Cladosporium OTUs accounted for up to $26 \%$ of the mycoplankton communities, with nine of the libraries collected from the deep chlorophyll maximum (DCM) and coinciding with high phytoplankton biomass (Fig. 2D).

\section{Discussion}

Stringent analysis of $13018 \mathrm{~S}$ rRNA gene libraries from six coastal marine sites showed that Malassezia and Cladosporium are consistent components of other coastal mycoplankton assemblages (Richards et al., 2015), and as with Cladosporium shown here, we have previously shown that Malassezia are abundant specifically at Station L4 (Taylor and Cunliffe, 2016). Both genera have also been shown in other studies to be prevalent in other pelagic marine ecosystems, including the open ocean (Amend, 2014; Wang et al., 2014).

The functional roles that aquatic fungi undertake in food webs and associated biogeochemical processes are currently poorly understood (Grossart and Rojas-Jimenez, 2016). Here we provide empirical evidence of active marine mycoplankton saprotrophy, identifying specific taxa that utilise algal-derived polysaccharide microgels (Fig. 2E). Utilisation of algal-derived polysaccharides is a role already established in some marine bacterioplankton (Buchan et al., 2014; Taylor and Cunliffe, 2017), suggesting that possible ecological interactions (e.g. competition, syntrophy) between saprotrophic mycoplankton and bacterioplankton could be taking place that are yet to be understood. Marine fungi, including Cladosporium, are potential prey for some zooplankton (Hu et al., 2015), indicating that mycoplankton may have a carbon transfer role from algal-derived POC to higher trophic levels (Fig. 2E). Saprotrophic mycoplankton activity in the coastal carbon cycle must now be quantified and, with the discovery that fungi also dominate living biomass on marine snow (Bochdansky et al., 2017), the activity of mycoplankton in the open ocean should also be explored.

\section{Acknowledgments}

We thank the captain and crew of the RV Plymouth Quest for facilitating sample collection. Supporting environmental data used in this study were provided by the Western Channel Observatory, which is funded as part of the UK Natural Environmental Research Council's National Capability. We particularly thank Claire Widdicombe (Plymouth Marine Laboratory) for providing the phytoplankton abundance data. A Marine Biological Association (MBA) Research Fellowship awarded to MC funded this research.

\section{Supplementary data}

Supplementary data related to this article can be found at http:// dx.doi.org/10.1016/j.funeco.2017.08.009.

\section{References}

Amend, A., 2014. From dandruff to deep-sea vents: Malassezia-like fungi are ecologically hyper-diverse. PLoS Pathog. 10, e1004277.

Bochdansky, A.B., Clouse, M.A., Herndl, G.J., 2017. Eukaryotic microbes, principally fungi and labyrinthulomycetes, dominate biomass on bathypelagic marine snow. ISME J. 11, 362-373.

Buchan, A., LeCleir, G.R., Gulvik, C.A., González, J.M., 2014. Master recyclers: features and functions of bacteria associated with phytoplankton blooms. Nat. Rev. Microbiol. 12, 286-298.

Cunliffe, M., 2016. Purine catabolic pathway revealed by transcriptomics in the model marine bacterium Ruegeria pomeroyi DSS-3. FEMS Microbiol. Ecol. 92 http://dx.doi.org/10.1093/femsec/fiv1150.

de Vargas, C., Audic, S., Henry, N., Decelle, J., Mahé, F., Logares, R., Lara, E., Berney, C., Le Bescot, N., Probert, I., Carmichael, M., Poulain, J., Romac, S., Colin, S., Aury, J.M., Bittner, L., Chaffron, S., Dunthorn, M., Engelen, S., Flegontova, O., Guidi, L., Horák, A., Jaillon, O., Lima-Mendez, G., Lukeš, J., Malviya, S., Morard, R. Mulot, M., Scalco, E., Siano, R., Vincent, F., Zingone, A., Dimier, C., Picheral, M. Searson, S., Kandels-Lewis, S., Acinas, S.G., Bork, P., Bowler, C., Gorsky, G. Grimsley, N., Hingamp, P., Iudicone, D., Not, F., Ogata, H., Pesant, S., Raes, J., Sieracki, M.E., Speich, S., Stemmann, L., Sunagawa, S., Weissenbach, J. Wincker, P., Karsenti, E., Boss, E., Follows, M., Karp-Boss, L., Krzic, U. Reynaud, E.G., Sardet, C., Sullivan, M.B., Velayoudon, D., 2015. Eukaryotic plankton diversity in the sunlit ocean. Science 348.

Engel, A., Delille, B., Jacquet, S., Riebesell, U., Emma, R.-N., Terbrüggen, A., Zondervan, I., 2004. Transparent exopolymer particles and dissolved organic carbon production by Emiliania huxleyi exposed to different $\mathrm{CO}_{2}$ concentrations: a mesocosm experiment. Aquat. Microb. Ecol. 34, 93-104.

Ford, C.W., Percival, E., 1965. The carbohydrates of Phaeodactylum tricornutum. J. Chem. Soc. 7035-7041.

Grossart, H.P., Rojas-Jimenez, K., 2016. Aquatic fungi: targeting the forgotten in microbial ecology. Curr. Opin. Microbiol. 31, 140-145.

Gutiérrez, M.H., Pantoja, S., Tejos, E., Quiñones, R.A., 2011. The role of fungi in processing marine organic matter in the upwelling ecosystem off Chile. Mar. Biol. 158, 205-219.

Hoppe, H.G., 1983. Significance of exoenzymatic activities in the ecology of brackish water-measurements by means of methylumbelliferyl-substrates. Mar. Ecol. Prog. Ser. 11, 299-308.

Hu, S., Guo, Z., Li, T., Xu, C., Huang, H., Liu, S., Lin, S., 2015. Molecular analysis of in situ diets of coral reef copepods: evidence of terrestrial plant detritus as a food source in Sanya Bay, China. J. Plankton Res. 37, 363-371.

Neufeld, J.D., Vohra, J., Dumont, M.G., Lueders, T., Manefield, M., Friedrich, M.W. Murrell, J.C., 2007. DNA stable-isotope probing. Nat. Protoc. 2, 860-866.

Passow, U., 2002. Transparent exopolymer particles (TEP) in aquatic environments Prog. Oceanogr. 55, 287-333.

Richards, T.A., Jones, M.D.M., Leonard, G., Bass, D., 2012. Marine fungi: their ecology and molecular diversity. Annu. Rev. Mar. Sci. 4, 495-522.

Richards, T.A., Leonard, G., Mahé, F., del Campo, J., Romac, S., Jones, M.D., Maguire, F., Dunthorn, M., De Vargas, C., Massana, R., Chambouvet, A., 2015. Molecular diversity and distribution of marine fungi across 130 European environmental samples. Proc. R. Soc. B 282, 20152243.

Taylor, J.D., Cunliffe, M., 2014. High-throughput sequencing reveals neustonic and planktonic microbial eukaryote diversity in coastal waters. J. Phycol. 50 960-965.

Taylor, J.D., Cunliffe, M., 2016. Multi-year assessment of coastal planktonic fung reveals environmental drivers of diversity and abundance. ISME J. 10, $2118-2128$.

Taylor, J.D., Cunliffe, M., 2017. Coastal bacterioplankton community response to diatom-derived polysaccharide microgels. Environ. Microbiol. Rep. 9, 151-157.

Tisthammer, K.H., Cobian, G.M., Amend, A.S., 2016. Global biogeography of marine fungi is shaped by the environment. Fungal Ecol. 19, 39-46.

Wang, X., Singh, P., Gao, Z., Zhang, X., Johnson, Z.I., Wang, G., 2014. Distribution and diversity of planktonic fungi in the West pacific warm pool. PLoS One 9, e101523.

Worden, A.Z., Follows, M.J., Giovannoni, S.J., Wilken, S., Zimmerman, A.E., Keeling, P.J., 2015. Rethinking the marine carbon cycle: factoring in the multifarious lifestyles of microbes. Science 347. http://dx.doi.org/10.1126/ science.1257594. 